\title{
Rules and Regulations of the Federal National Council of the United Arab Emirates and the National Consultative Council of the Emirate of Abu Dhabi and their Functions within the Country's Socio-political Sphere ${ }^{1}$
}

\author{
By Monika Fatima Mühlböck
}

In 1968, when Britain announced its intention to withdraw from the Gulf area by the end of 1971, the rulers of the nine smaller Gulf states, Bahrain, Qatar, Abu Dhabi, Dubai, Sharjah, Ajman, Umm al-Qaiwain, Ras al-Khaimah, and Fujairah planned to agree a union called the Federation of the Arab Emirates. The Supreme Council, the highest body of the Federation, met four times between July 1968 and October 1969, before Bahrain and soon afterwards Qatar opted in favor of their own independence. ${ }^{2}$

Six of the seven remaining Trucial states, Abu Dhabi, Dubai, Sharjah, Ajman, Umm alQaiwain, and Fujairah joined together to form the United Arab Emirates on 2 December 1971, and the seventh Trucial state, Ras al-Khaimah, was admitted on 10 February $1972{ }^{3}$ The provisional constitution of the Federation had already been signed in Dubai on 18 July $1971{ }^{4}$

The lower Gulf has been operating under the traditional tribal system of governance for a long time, and, although the (provisional) constitution gives complete authority to the

1 This article is a revised version of the paper "Aufgaben und Ziele des Federal National Council (VAE) und des National Consultative Council (Abu Dhabi) in ihrem soziopolitischen Umfeld" delivered at the 4th Congress of the Deutsche Arbeitsgemeinschaft Vorderer Orient für gegenwartsbezogene Forschung und Dokumentation (DAVO) in Hamburg, Germany, in December, 1997. Typing errors, articles etc. in the laws have been corrected. Besides that, a standardisation of the use of the large and small case letters in words such as, emirate, council, committee and law has been carried out. For clarity the outward form of the laws has been adapted. Further changes to the of ficial English translations have not been made. The transcription of "The Encyclopaedia of Islam", common $E I^{2}$, has been used.

Muhammad T. Sadik / William P. Snavely, Bahrain, Qatar, and the United Arab Emirates, Colonial Past, Present Problems and Future Prospects. Lexington, Massachusetts 1972, pp. 187197.

Ibid., pp. 187, 199 and Ibrahim Al Abed / Paula Vine / Abdullah Al Jabali (eds.), Chronicle of Progress, 25 Years of Development in the United Arab Emirates, London 1996, p. 18.

Ministry of Information, United Arab Emirates, Provisional Constitution of the United Arab Emirates [Abu Dhabi approx. 1972], p. 41. 
Supreme Council, which consists of the rulers of all emirates, and makes them the focal point of control, yet, the attempt to define rule and responsibility and to state power and authority of the various organs of the union as well as to recognize the need for the participation of the people in the process of government was the first healthy sign towards building a state in the modern sense. ${ }^{5}$

\section{Traditional Government}

To suppress piracy and the slave-trade, Britain tried to reach agreements with the sheikhs in this region from 1806 onwards, thus interfering in their policy and sovereignty, ${ }^{6}$ whereas the tribal and, therefore, traditional reign was in the hands of the local sovereign. Generally, the ruler of an emirate, the sheikh, was the leader of the most powerful, though not necessarily the most populous tribe, while each individual tribe, and often its various subsections, also had a chief or sheikh.

At a time when communication was slow between the scattered settlements of the sheikhdoms of this area, each ruler maintained permanent representatives, usually called wali, in the more important centres of population within his territory. The fact that his representative controlled this area meant that the ruler's authority was at least de jure recognized by the population of that remote area and by the neighbouring sheikhs. But often enough control over the representative himself slipped from the ruler's hands, and he declared himself an independent sovereign. The more extensive the geographical area of the sheikhdom, the greater the wali's political clout. While camels and sailing boats were the principal means of transport throughout the years, the administration of a large sheikhdom could not easily be centralized.'The extent to which a ruler's personal influence was felt in the distant settlements under his sovereignty depended on the geographical and economic situation as much as on his choice of the wali. The closer the ties of genuine mutual trust between ruler and wali, the more it was possible to delegate authority without running the risk of secession. For precisely this reason most rulers put a brother or a son in charge of an important "dependency". 8

See ibid., pp. 1-41.

6 Eberhard Wohlfahrt, Die Arabische Halbinsel, Länder zwischen Rotem Meer und Persischem Golf, Berlin 1980, pp. 915-917, 921 and $E I^{2}$ I, p. 166 and $E I^{2}$ II, p. 619 and $E I^{2}$ VIII, p. 436 and $E I^{2}$ IX, p. 349 and $E I^{2}$ Supplement Fasc. 1-2, p. 42.

Peter J. Vine / Peter Hellyer / Ibrahim El-Abed (eds.), UAE, Yearbook 1995, London 1995, p. 27.

8 Frauke Heard-Bey, From Trucial States to United Arab Emirates, A Society in Transition. London 1996, p. 81. 
The sheikhs, chiefs and walis maintained their authority only insofar as they were able to retain the loyalty and support of their people, in essence - as understood in the traditionally-minded Gulf society - a form of direct democracy, though without the paraphernalia of western forms of suffrage. Part of that democracy was the unwritten but strong principle that the people should have free access to their sheikh, and that he should hold a frequent and open madjlis, or council, in which his fellow tribesmen could voice their opinions. In smaller emirates, the madjlis of the ruler himself, or of the crown-prince or deputy ruler, remains the main focus even today.

In the United Arab Emirates, however, the rulers decided to adopt a different approach; that of creating modern forms of administration including direct democracy, in the form of the Federal National Council and the National Consultative Council, but, at the same time, preserving traditional institutions, like the madjlis, with the vitality and legitimacy they draw from history. ${ }^{9}$

\section{Federal Government}

In June 1975, a committee was appointed to draft a permanent federal constitution, but when the Supreme Council convened on 12 July 1976, and no agreement had been reached over the new constitution, it decided on an extension of the provisional constitution for another five years from 2 December 1976 to 1 December 1981, and for further periods of five years in December 1981, 1986 and 1991. Eventually, legislation was designed to make the provisional constitution permanent, and, on 20 May 1996, the Supreme Council approved the amendment to the provisional constitution which would delete the term 'provisional' from its clauses, ${ }^{10}$ the details of which will be discussed later on.

According to Article 45 of the constitution the country's authorities consist of the Supreme Council of the Union, now called the Supreme Council of the Federation, the president and his deputy, the Council of Ministers, the National Assembly of the Union, now called the Federal National Council, and the Judiciary of the Union, now called the Federal Judiciary. ${ }^{11}$ The current president, who has held this office since the creation of the United

9

Peter J. Vine / Peter Hellyer / Ibrahim El-Abed (eds.), op.cit., pp. 27-29 and Monika Mühlböck, Die Entwicklung der Massenmedien am Arabischen Golf, Heidelberg 1988, p. 44.

10

The Middle East and North Africa 1997, The United Arab Emirates. London 1996, p. 1050 and Abdullah Omran Taryam, The Establishment of the United Arab Emirates 1950-85. London 1987, p. 236 and Ibrahim Al Abed / Paula Vine / Abdullah Al Jabali (eds.), op.cit., pp. 83, 98, 412.

11

Ministry of Information, United Arab Emirates, op.cit., p. 10 and Ibrahim Al Abed / Peter Hellyer I Paula Vine (eds.), United Arab Emirates, Yearbook 1997. London 1997, pp. 32, 36, 37 and alMadjlis al-Wațanī al-Ittiḥādī (1), Al-dustūr al-mu'aḳḳat li-dawlat al-Imārāt al- ${ }^{\mathrm{c}}$ Arabiyya al- 
Arab Emirates, is Zāyid b. Sultān Āl Nahayyān, Ruler of the Emirate of Abu Dhabi. Since 21 October 1990 his deputy has been the Vice-President and Prime Minister Maktūm b. Rāshid Āl Maktūm, Ruler of the Emirate of Dubai. ${ }^{12}$

\section{Federal National Council ${ }^{13}$ (al-ma dilis al-watanī al-ittiḥādī)}

The 152 articles containing the constitution deal, in Part Four, Chapter IV, with 'The National Assembly of the Union' only, by stating:

\section{Section 1 - General Provisions}

Article 68

The National Assembly of the Union shall be composed of forty ${ }^{14}$ members. Seats shall be distributed to member emirates as follows: Abu Dhabi: 8 seats; Dubai: 8 seats; Sharjah: 6 seats; Ras al-Khaimah: 6 seats; Ajman: 4 seats; Umm al-Qaiwain: 4 seats; Fujairah: 4 seats.

\section{Article 69}

Each emirate shall be free to determine the method of selection of the citizens representing it in the National Assembly of the Union.

\section{Article 70}

A member of the National Assembly of the Union must satisfy the following conditions:

1. Must be a citizen of one of the emirates of the Union and permanently resident in the emirate he represents in the Assembly.

2. Must be not less than twenty-five Gregorian years of age at the time of his selection.

3. Must enjoy civil status, good conduct, reputation and not previously be convicted of a dishonourable offence unless he has been rehabilitated in accordance with the law.

4. Must have adequate knowledge of reading and writing.

\section{Article 71}

Membership of the National Assembly of the Union shall be incompatible with any public office in the Union, including ministerial portfolios.

Muttahida wa-'l-lā'iḥa al-dākhiliyya li-'l-madjlis al-wāțanī anial-ittiḥādī wa-'l-niẓām al-dākhili li'l-shu u'ba al-barlamāniyya. Abū Zabī 1995, p. 9. The of ficial English translation of the permanent constitution using the new terms of the authorities was not available until the end of June 1998.

Ibrahim Al Abed / Peter Hellyer / Paula Vine (eds.), op.cit., pp. 30, 32 and Ibrahim Al Abed / Paula Vine I Abdullah Al Jabali (eds.), op.cit., pp. 14, 327. Situation covered until end of June 1998.

In accordance with today's terminology, the author will use the new term when not quoting the of ficial English text of the former provisional constitution. 


\section{Article 72}

The term of membership in the National Assembly of the Union shall be two Gregorian years commencing from the date of its first sitting. When this period expires, the Assembly shall be completely renewed for the time remaining until the end of the transitional period as laid down in Article 144 of this constitution.

Any member who has completed his term may be re-elected.

\section{Article 73}

Before assuming his duties in the Assembly or its committees, a member of the National Assembly of the Union shall take the following oath before the Assembly in public session:

"I swear by Almighty God that I will be loyal to the United Arab Emirates; that I will respect the constitution and the laws of the Union and that I will discharge my duties in the Assembly and its committees honestly and truthfully."

\section{Article 74}

If, for any reason, a seat of any member of the Assembly becomes vacant before the end of the term of his membership, a replacement shall be selected within two months of the date on which the vacancy is announced by the Assembly, unless the vacancy occurs during the three months preceding the end of the term of the Assembly.

The new member shall complete the term of membership of his predecessor.

\section{Article 75}

Sessions of the National Assembly of the Union shall be held in the Union's capital. Exceptionally, sessions may be held in any other place within the Union on the basis of a decision taken by a majority vote of the members and with the approval of the Council of Ministers.

\section{Article 76}

The Assembly shall decide upon the validity of the mandate of its members. It shall also decide upon disqualifying members, if they lose one of the required conditions, by a majority of all its members and on the proposal of five among them. The Assembly shall be competent to accept resignation from membership. The resignation shall be considered as final from the date of its acceptance by the Assembly.

\section{Article 77}

A member of the National Assembly of the Union shall represent the whole people of the Union and not merely the emirate which he represents in the Assembly.

\section{Section 2 - Organisation of Work in the National Assembly of the Union}

\section{Article 78}

The Assembly shall hold an annual ordinary session lasting not less than six months, commencing in the third week of November each year. It may be called into extraordinary session whenever the need arises. The Assembly may not consider at an extraordinary session any matter other than those for which it has been called into session.

Notwithstanding the preceding paragraph, the president of the Union shall summon the National Assembly of the Union to convene its first ordinary session within a period not exceeding sixty days from the entry into force of this constitution. This session shall end at the time appointed by the Supreme Council by decree. 


\section{Article 79}

The Assembly shall be summoned into session, and its session shall be terminated by decree issued by the president of the Union with the consent of the Council of Ministers of the Union. Any meeting held by the Assembly ${ }^{15}$ without a formal summons, or in a place other than that legally assigned for its meeting in accordance with this constitution, shall be invalid and shall have no effect.

Nevertheless, if the Assembly is not called to hold its meeting for its annual ordinary session before the third week of November, the Assembly shall be ipso facto in session on the twenty-first of the said month.

\section{Article 80}

The president of the Union shall inaugurate the ordinary annual session of the Assembly, whereupon he shall deliver a speech reviewing the situation of the country and the important events and affairs which happened during the year and outlining the projects and reforms, the Union Government plans to undertake during the new session. The president of the Union may depute his vice-president or the prime minister to open the session or to deliver the speech.

The National Assembly of the Union shall select, from among its members, a committee to draft the reply to the opening speech, embodying the Assembly's observations and wishes, and shall submit the reply after approval by the Assembly to the president of the Union for submission to the Supreme Council.

\section{Article 81}

Members of the Assembly shall not be censured for any opinions or views expressed in the course of carrying out their duties within the Assembly or its committees.

\section{Article 82}

Except in cases of flagrante delicto, no penal proceedings may be taken against any member while the Assembly is in session, without the authorisation of the Assembly. The Assembly must be notified if such proceedings are taken while it is not in session.

\section{Article 83}

The president of the Assembly and its other members shall be entitled, from the date of taking the oath before the Assembly, to a remuneration which shall be determined by law, and to travelling expenses from their place of residence to the place in which the Assembly is meeting.

\section{Article 84}

The Assembly shall have a bureau consisting of a president, a first and second vice-president and two controllers. The Assembly shall select them all from among its members.

The term of office of the president and the two vice-presidents shall expire when the term of the Assembly expires or when it is dissolved in accordance with the provisions of the second Paragraph of Article 88.

The term of office of the controllers shall expire with the choice of new controllers at the opening of the next ordinary annual session. If any post in the bureau becomes vacant, the Assembly shall elect who shall fill it for the remaining period. 


\section{Article 85}

The Assembly shall have a secretary-general who shall be assisted by a number of staff who shall be directly responsible to the Assembly. The Assembly's standing orders shall lay down their conditions of service and their powers.

The Assembly shall lay down its standing orders, issued by decree promulgated by the president of the Union with the consent of the Council of Ministers.

The standing orders shall define the powers of the president of the Assembly, his two vice-presidents and the controllers and shall define generally all matters pertaining to the Assembly, its committees, its members, its secretariat, its employees, its rules and procedures of discussion and voting in the Assembly and the committees and other matters within the limits of the provisions of this constitution.

Article 86

Sessions of the Assembly shall be public. Secret sessions may be held at the request of a representative of the government, the president of the Assembly or one third of its members.

\section{Article 87}

Deliberations of the Assembly shall not be valid unless a majority of its members at least are present. Resolutions shall be taken by an absolute majority of the votes of members present, except in cases where a special majority has been prescribed. If votes are equally divided, the side which the president of the session supports shall prevail.

Article 88

Meetings of the Assembly may be adjourned by a decree promulgated by the president of the Union with the approval of the Council of Ministers of the Union for a period not exceeding one month, provided that such adjournment is not repeated in one session except with the approval of the Assembly and for once only. The period of adjournment shall not be deemed part of the term of the ordinary session.

The Assembly may also be dissolved by a decree promulgated by the president of the Union with the approval of the Supreme Council of the Union, provided that the decree of dissolution includes a summons to the new Assembly to come into session within sixty days of the date of the decree of dissolution. The Assembly may not be dissolved again for the same reason.

\section{Section 3 - Powers of the National Assembly of the Union}

Article 89

In so far as this does not conflict with the provisions of Article 110, Union bills, including financial bills, shall be submitted to the National Assembly of the Union before their submission to the president of the Union for presentation to the Supreme Council for ratification. The National Assembly of the Union shall discuss these bills and may pass them, amend or reject them.

\section{Article 90}

The Assembly shall examine during its ordinary session the annual general budget draft law of the Union and the draft law of the final accounts, in accordance with the provisions in Part ${ }^{16}$ Eight of this constitution. 
Article 91

The govermment shall inform the National Assembly of the Union of intermational treaties and agreements concluded with other states and the various intemational organisations, together with appropriate explanations.

\section{Article 92}

The National Assembly of the Union may discuss any general subject pertaining to the affairs of the Union unless the Council of Ministers informs the National Assembly of the Union that such discussion is contrary to the highest interests of the Union. The prime minister or the minister concerned shall attend the debates. The National Assembly of the Union may express its recommendations and may define the subjects for debate. If the Council of Ministers does not approve of these recommendations, it shall notify the National Assembly of the Union of its reasons.

\section{Article 93}

The government of the Union shall be represented at sessions of the National Assembly of the Union by the prime minister or his deputy or one member of the Union cabinet at least. The prime minister or his deputy or the competent minister, shall answer questions put to them by any member of the Assembly requesting explanation of any matters within their jurisdiction, in conformity with the procedures prescribed in the standing orders of the Assembly.

Ras al-Khaimah, holding six seats in the Federal National Council, as mentioned in Article 68 , had originally refrained from joining the Federation, among other reasons, in protest against the allocation of seats in this body. When the United Arab Emirates was established in late 1971, Ras al-Khaimah pressed for the same representation as that of Abu Dhabi and Dubai, but it ultimately agreed to its present level of representation. ${ }^{18}$ The ruler of Ras alKhaimah could hardly cope with the fact, that his emirate should not be given that leading role within the Federation, contradicting its role throughout history. ${ }^{19}$

The Federal National Council's major activity is confined to debating bills forwarded to it by the Council of Ministers. Though it is entitled to enter amendments, by addition or omission, and even to approve or disapprove, it cannot impose anything on the Supreme Council, since the latter, as well as the president, reserves the constitutional right to promulgate laws, irrespective of approval or disapproval by the Federal National Council. Thus the powers of this body are very limited. It cannot propose bills, as that privilege is reserved for the executive as represented by the Council of Ministers. The Federation of the United Arab Emirates does not, therefore, have a legislative body in the real sense, but

Ministry of Information, United Arab Emirates, op.cit., pp. 18-24. The Arabic text see al-Madjlis al-Watani al-Ittihādī (1), op.cit., pp. 17-22 and the decision of the Supreme Council of the Union No. 3, 1972 dated from 10 February 1972 see p. $46 \mathrm{f}$.

Muhammad T. Sadik / William P. Snavely, op.cit., p. 199 f.

19

$E I^{2}$ Supplement Fasc. 5-6, p. 418 and see $E I^{2}$ VIII, p. 435 f. 
rather a body with a limited scope, whose role is restricted to consultation and making recommendations. ${ }^{20}$

Article 110, Paragraph 3.a., stipulates the following:

If the National Assembly of the Union inserts any amendment to the bill and this amendment is not acceptable to the president of the Union or the Supreme Council, or if the National Assembly of the Union rejects the bill, the president of the Union or the Supreme Council may refer it back to the Assembly. If the National Assembly of the Union introduces any amendment on that occasion which is not acceptable to the president of the Union or the Supreme Council, or if the National Assembly of the Union decides to reject the bill, the president of the Union may promulgate the law after ratification by the Supreme Council. 21

In the case that the Federal National Council is not in session, the law is such that it will only be informed of changes after the event, as Article 110, Paragraph 4, declares:

Notwithstanding the foregoing, if the situation requires the promulgation of Union laws when the National Assembly of the Union is not in session, the Council of Ministers of the Union may issue them through the Supreme Council and the president of the Union, provided that the Assembly is notified at its next meeting. 22

However, in accordance with Article 78, it is possible to call the Federal National Council into an extraordinary session should the need arise. But, when this body is summoned into meeting, it is dependent on the president going into consultation with the Supreme Council. $^{23}$

The regulations concerning the time-table of the Federal National Council as stated in Articles 78 and 79 do not seem to have been fulfilled in the last years, whereas frequent sessions, even extraordinary and emergency ones, took place during the state's developmental period. ${ }^{24}$ In avoidance of any influence from the very beginning, Article 79 mentions, among others, that any meeting held without an official summons is invalid and without effect.

Abdullah Omran Taryam, op.cit., p. 204.

Ibid.

23 The author learned of this in a personal talk with Hasan al-Anșārī, Director for Parliamentary Affairs at the Federal National Council in Abu Dhabi in November 1997.

24

An of ficial list of sessions is not available, but see under Federal National Council in Ibrahim Al Abed / Paula Vine / Abdullah Al Jabali (eds.), op.cit., p. 425. 
Other factors contributing to the weakness of the Federal National Council can be found, for instance, in Article 70, Paragraph 1, where membership of this body is made on the condition that a representative is a citizen of one of the seven emirates and in permanent residence there. This, in effect, creates a different sense of nationalism, contradicting the idea of a single nationality within the Federation as stated in Article $8 .{ }^{25}$ Furthermore, in compliance with the Articles 69 and 70, Paragraphs 3 and 4, an emirate is left free to select the persons to represent it at the Federal National Council and in the manner it sees fit. This also contradicts Article 77 which stipulates, that a member of this Council shall be a deputy for the Federation people at large, and not only act as a representative of his emirate within this body. This means Article 77 is incompatible with Article $69 .{ }^{26}$

Invariably it is the rulers' own choice to select representatives, since none of the seven emirates is ruled according to a written constitution. ${ }^{27}$ As happened when the traditional forms of tribal administration, described above, still characterized every day life, the ruler of each emirate will only delegate a person drawn from among his territory's main tribes and families, of whom he is assured loyalty and is already in the sovereign's confidence. However, in practice, the chosen member faces a dilemma produced by his keenness to serve the Federation, while at the same time he has to take account of the particular desires of the emirate whose ruler has chosen him for this body's membership. ${ }^{28}$

\section{Facts on the Development of Federal National Council}

On 13 February 1972 the Federal National Council was formally established, and the members took the constitutional oath. ${ }^{29}$ The Council has eight sub-committees empowered with the study of draft laws referred to it from the Council of Ministers, they also handle complaints and appeals. These committees deal with: Defence and Interior, Financial and Economic Affairs, Judicial and Legislative Affairs, Health, Labour, Social Affairs, Education, Youth, Information and Culture, Foreign Affairs, Planning, Oil, Mineral Resources, Agriculture, Fisheries Affairs, Islamic and Endowment, and Public Places. ${ }^{30}$

Abdullah Omran Taryam, op.cit., p. 206 and Ministry of Information, United Arab Emirates, op.cit., p. 3.

Abdullah Omran Taryam, op.cit., p. 206 f.

Ibid., p. 207 and Peter J. Vine / Peter Hellyer / Ibrahim El-Abed (eds.), op.cit., p. 24.

Al-Madjlis al-Wațanī al-Ittilıādì (2), Sanawāt min 'umr al-ittihāàd. Dubayy 1996, p. 20 and Ibrahim Al Abed / Paula Vine / Abdullah Al Jabali (eds.), op.cit., p. 18. 
Since its formation and up to the end of 1997 the Council has had four presidents, these being: Thānī b. 'Abd Allāh from 12 February 1972 until 1 December 1976, Taryam b. 'Umrān b. Taryam from 1 March 1977 until 1 December 1981, Hilāl b. Ahmad b. Lūtāh from 28 December 1981 until 1 December 1991, and al-Ḥādidj b. 'Abd Allāh alMuhayrabī, who has held this position since 6 December 1993 . $^{31}$

International news agencies announced, in early 1997, that women in the United Arab Emirates would be allowed to become members to the Federal National Council for the first time. ${ }^{32}$ However, a special office of the Federal National Council had already been opened in Dubai on 4 April $1972 .{ }^{33}$ As for external matters, the Council is a member of both, the Arab Parliamentary Union, of which it gained approved membership on 25 April $1973^{34}$, according to other sources in March $1975^{35}$, and the International Parliamentary Union, having been accepted on 20 September $1977 .^{36}$

The Council participated in many regional parliamentary meetings, such as the Arab-European and African dialogues, and exchanged visits with similar councils in Arab and friendly states. On 24 April 1985, for instance, a session of official discussions was held in the United Arab Emirates between delegations from the Federal National Council and the Syrian People's Council concerning Arab and international matters of mutual interests. A joint communique on the results of the discussions between the Council and the British House of Commons Committee was disseminated on 12 December $1986 .^{37}$

A large-scaled construction topped with a blue dome, surrounded by a huge park, became the new building of the Federal National Council from 19 June 1989 onwards, situated next to the Ministry of Justice and the elegant Corniche Road in Abu Dhabi. ${ }^{38}$

31

Al-Madjlis al-Watanī al-Ittihādì (2), op.cit., p. 157 f.

Gesellschaft für Österreichisch-Arabische Beziehungen, Bulletin der Gesellschaft für Österreichisch-Arabische Beziehungen, No. 1/97, Vienna 1997, p. 12.

Ibrahim Al Abed / Paula Vine / Abdullah Al Jabali (eds.), op.cit., p. 20.

Ibid., p. 43.

Al-Madjlis al-Watanī al-Ittihāà̄ (2), op.cit., p. $161 \mathrm{f}$.

Ibrahim Al Abed / Paula Vine / Abdullah Al Jabali (eds.), op.cit., p. 118 and al-Madjilis alWatanī al-Ittihäaì (2), op.cit., p. 174.

Ibrahim Al Abed / Peter J. Vine / Paula Vine (eds.), op.cit., p. 37 and Ibrahim Al Abed / Paula Vine / Abdullah Al Jabali (eds.), op.cit., pp. 43, 118, 243, 269 and al-Madjlis al-Watani alIttihädī (2), op.cit., pp. 159-176.

Ibrahim Al Abed / Peter J. Vine / Paula Vine (eds.), op.cit., p. 306 and al-Madjlis al-Watanī alIttilıädī (2), op.cit., p. 167. 
Regarding internal matters, from the date of its establishment in February 1972 until December 1996, the Council had reached into the tenth legislative period. During all these terms, 25 ordinary sessions and four extraordinary or emergency sittings took place, assembling the members of this body in 295 meetings. ${ }^{39}$ At the time this research was carried out, the last sittings of the Council were convened on 23 and 30 June $1998 .^{40}$

Until late 1996, this body had discussed and ratified 294 draft laws, and also debated 182 subjects concerned with the country and its nationals, in addition to the general policies of federal ministries. The member of the Council presented more than 100 questions to the concerned ministers about national affairs and the policies of the ministries dealing with them. ${ }^{41}$ It also dealt with international matters and bilateral relations. ${ }^{42}$ Some of the body's recommendations and agreements are noteworthy in one way or another: The Council recommended on 6 February 1974, that a draft law be prepared encouraging male nationals to marry United Arab Emirates women and to increase the number of children. A draft law, regarding firearms, ammunitions and explosives, authorizing stiff penalties for violators of this law, became approved on 5 June 1974.

The Supreme Council of the Federation (from which the Emirate of Dubai was absent) discussed, on 19 March 1979, a Council of Ministers and Federal National Council memorandum to unify emirate boundaries, create a central bank and unite the armed forces. On 14 July 1986, the Council of Ministers debated the rise in marriages between United Arab Emirates men and foreign women in light of the recommendations of the Federal National Council on the necessity of combating this phenomenon for social reasons. The body recommended the death penalty for drug traffickers and dealers on 12 April 1988.

The meeting on 1 April 1996 between the joint committee of the Federal National Council and the Council of Ministers endorsed the laying-down of a comprehensive strategy to train and employ United Arab Emirates citizens. The Federal National Council advised the inclusion of workers in the private sector in the draft law on retirement, and it called on the private sector to eliminate obstacles to the employment of national cadres.

A few days later, on 9 April 1996, the Council recommended the setting-up of a supreme board for the appointment of United Arab Emirates citizens and to further develop the

39

40

41

42

Ministry of Information and Culture, United Arab Emirates, The United Arab Emirates 1993. Dubai 1993, p. 19 and Ibrahim Al Abed / Paula Vine / Abdullah Al Jabali (eds.), op.cit., e.g. pp. $51,189,242,245,259,260,267,362,376,380$ f., 413. 
issues of national manpower. At the same time it approved the changes in the Immigration and Residence Law to include the imposition of harsh punishments on persons who harbor illegal immigrants, and on those who have helped them enter the country. ${ }^{43}$

\subsection{Committee for a Draft Permanent Constitution}

As already mentioned above, in June 1975 a committee was nominated to draft a permanent constitution for the country. The draft accorded the Federal National Council an appropriate status, presumably for the future, ridding it of its predominantly consultative character and granting it the right to actual participation in government. Moreover, it changed the old manner of representation in the Council by which, under the former provisional and now permanent constitution, a certain number of seats was allotted to each emirate in accordance with Article 68.

Instead, Article 63 of the draft stipulated that: 'The National Assembly of the United Arab Emirates shall be composed of 60 members who shall be divided among the seven member emirates according to the number of nationals in each of them.' This was a gesture towards unity, since the member was apparently viewed as a representative of the people, rather than of the government of an emirate. Moreover, the prime minister, deputy prime minister and ministers were to be ex officio members of the Council. Article 87 of the draft gave the body the right to initiate bills, which was unheard of before. Article 93 gave it the right to question the prime minister, the deputy prime minister and ministers about matters related to their respective functions, while Article 94 gave it the right to withdraw confidence from a minister, though not from the prime minister or the deputy prime minister.

However, it was obvious from the very beginning that Dubai was pressing for an extension of the life of the provisional constitution for another five years on the ground that ample time should be provided for the evaluation of the federal experiment. Dubai also saw to it that it did not relinquish its powers to the federal institutions, fearing that the process might end with all powers concentrated in the hands of a single ruler. Ras al-Khaimah maintained a similar stand, but Abu Dhabi and Sharjah were enthusiastic about the permanent constitution which was intended to eradicate the negative aspects frustrating the union. The composition of the committee, which engaged in numerous sittings, was not helpful. The preparation of a draft constitution, whose major provisions were already agreed, was not a job which needed 28 members, most of whom were not lawyers, but simply represented their respective emirates. Eventually, the committee's activity became largely ceremonial. Moreover, it was reminiscent of those pre-union meetings which had been characterized by 410 . 
lobbying. The Dubai delegation included those who were known for their ability to convey and carry out the wishes of the emirate. One member of this delegation was of the opinion that the new constitution should not be adopted as a whole, but rather a step-by-step gradual process should be sought.

The committee meetings oscillated between division and agreement, especially with regard to provisions aimed at strengthening the federal institutions by according them more functions and powers. The controversy concerned in particular the Federal National Council, the president of the state and budgetary contributions. The committee continued its discussions fruitlessly while the expiry date of the provisional constitution was approaching, thus signaling the possibility of a constitutional crisis. Accordingly, a flurry of exchanged sessions and visits started, and in the process, Abu Dhabi insisted on the replacement of the provisional constitution by a permanent one, while Dubai adamantly rejected this. Ras alKhaimah followed suit.

It was the upholders of the status quo, fearful of any change, who predominated in the face of any counter-bids. As the issue of the constitution had to be decided six months before the expiry of the five-year-term of the provisional constitution, the Supreme Council had to make a decision, either for the new constitution or for an extension of the existing one. Accordingly, when the Supreme Council met on 12 July 1976, and no understanding was achieved over the new constitution, it settled on an extension of the provisional constitution for another five years from 2 December 1976 to 1 December 1981. At this sitting the Supreme Council also was invited to convene in an extraordinary session to consider the measures for constitutional change. On 6 November 1976 the Supreme Council decided to amend the provisional constitution by adding the clause that only the Federation had the right to establish armed forces.

In accordance with the constitution, the Federal National Council was invited to assemble in order to debate a resolution to extend the term of the provisional constitution. During the extraordinary meeting, which took place on 12 October 1976, a number of trends emerged. One expressed disapproval of the extension on the grounds that it implied a further weakening of the union and that the Council would not be able to play a positive role. A second trend demanded amendments to certain sections of the provisional constitution if the extension was to be approved at all. A third trend, represented by members of the Emirates of Dubai and Ras al-Khaimah, as well as a number of members from other emirates, supported outright concurrence with the Supreme Council resolution favoring extension. Many members, however, tried actively, as a last bid, to persuade the body into exerting pressure 
upon the Supreme Council, but in a heated debate, the pro-extension trend won the day and an extension was approved. ${ }^{44}$

\subsection{Joint Committee of the Council of Ministers and the Federal National Council}

On 3 January 1977 a new Council of Ministers, composing of 23 ministers, was formed. Obviously to make the nature of the cabinet more nationally representative and more competent, 15 ministers were not members of ruling families, and ten of them were university graduates. Also a new Federal National Council was created, many of whose members believed in the future of the Federation.

The following period was characterized by a closer collaboration between the Council of Ministers and the Federal National Council. Unionists became more vocal in their demands for reform and more powers for the federal authority and this was exemplified in debates in the Council which were strikingly more forceful and candid. Mistakes and contraventions were openly pointed out, ministers were questioned closely, and successive memoranda about problems facing the country and proposed solutions were submitted to the Supreme Council. At the opening of each new session the Federal National Council president's address, delivered in the presence of all the rulers, usually dealt with a host of issues related to the union as well as negative factors confronting it and how they could be overcome. The address also included direct critical references to failures to consolidate the federal authority and grant it more powers. 45

On 27 June 1978, the Federal National Council convened a sitting, which the deputy prime minister and all the ministers were invited to attend. The debate dealt with domestic affairs concerning the higher interests of the state and its citizens, and it was decided to appoint a joint committee from both sides. The Council representatives on the committee were eight members including the president of this body, while the cabinet was represented by the deputy prime minister (in the chair) and six ministers.

The committee met for the first time on 5 July 1978 to discuss its assignment, and then adopted a program of visits to the rulers in order to hear their views and observations. These were intended to help the committee to formulate distinct and practical solutions to overcome existing difficulties, and thus submit definite recommendations to the Supreme

Abdullah Omran Taryam, op.cit., pp. 234-236 and Frauke Heard-Bey, op.cit., p. 377 and Ibrahim Al Abed / Paula Vine / Abdullah Al Jabali (eds.), op.cit., pp. 83, 98, 103 f. and see also pp. 71, 45 96.

Abdullah Omran Taryam, op.cit., p. 238 f. and Ibrahim Al Abed / Paula Vine / Abdullah Al Jabali (eds.), op.cit., p. 417 f. 
Council. ${ }^{46}$ The first ideas were presented on 23 July 1978, and under the subject 'the provisional constitution and the federal legislation' it suggested that 'Individual emirates should be consulted about federal bills before these were put before the Assembly, and the emirates should respond to them. ${ }^{47}$ Since that time, the joint committee has drawn up several suggestions, for instance, a ten-point memorandum containing comprehensive proposals for dealing with internal difficulties, which the president of the state received on 13 February 1979. The committee also completed a comprehensive report on the United Arab Emirate's economic situation for submission to the Supreme Council on 30 April 1985.

On 15 December 1985 the Supreme Council held a session in which a committee was formed specifically to study recommendations of the joint committee. And, on 12 October 1986, the Supreme Council discussed a memorandum of the committee regarding the consolidation of the country. The sitting of the joint committee on 1 April 1996, which endorsed the laying-down of an extensive strategy to train and employ nationals of the United Arab Emirates, has already been mentioned above.

Further details and background information concerning the joint committee were not available, but the co-operation seems to have been fruitful in some way for the country's development, although the president of the Federation called for support of the joint committee at the opening of the new session of the Federal National Council on 4 December 1984 . He also stressed the importance of this co-operation, in order to meet the needs of the public on 15 January $1996 .{ }^{48}$ Besides the closer ties discussed, connections are mentioned with the cabinet as well as different ministries.

On 2 June 1986, the Council of Ministers reviewed the country's general educational policy in light of the Federal National Council's recommendations on the requirements of the Federation's development plans. 49

The Ministers of Foreign Affairs, Defence and Interior attended an emergency meeting of the Federal National Council on 28 January 1979, at a time of political crisis in the United Arab Emirates, where a number of important domestic matters were examined. On 22 January 1991, the Council confirmed its confidence and appreciation for the Ministry of the

Abdullah Omran Taryam, op.cit., p. 239 and Ibrahim Al Abed / Paula Vine / Abdullah Al Jabali (eds.), op.cit., p. 133.

Ibrahim Al Abed / Paula Vine / Abdullah Al Jabali (eds.), op. cit., p. 133 f. and Abdullah Omran Taryam, op.cit., pp. 239, 241.

Ibrahim Al Abed / Paula Vine /Abdullah Al Jabali (eds.), op.cit., pp. 141 f., 233, 243, 252, 264, $405,409$. 
Interior, and a so-called co-ordination committee became created from both institutions on 7 February 1996, to deal with a number of issues, including residential formations, immigration, residence, combating illegal entry into the country, and drugs. ${ }^{50}$

However, returning to chronological developments as far as the provisional constitution is concerned. The socio-political situation in the United Arab Emirates following the late 1970s is usually described as one of stagnation. By the end of 1981 no positive change had occurred; on the contrary, things turned out to be the opposite of what they had been between mid-1970s until 1979.

At a meeting of the Supreme Council on 28 October 1981 and an extraordinary session of the Federal National Council on 3 November 1981, the extension of the provisional constitution for another five years was announced, commencing on 2 December 1981 until beginning December $1986^{51}$

The further prolongation of the provisional constitution was made by the Supreme Council on 15 October 1986, again for a period of five years. ${ }^{52}$ None of the various sources available mention when the extension of the year 1986 as well as 1991 were submitted to the Federal National Council or the time it was notified. Whereas the meeting of the Supreme Council to extend the provisional constitution for another five years took place on 28 October 1991. During the meeting a committee dealing with constitutional changes was formed. ${ }^{53}$ Unfortunately no further information regarding this committee could be obtained.

Finally, in 1996, the rulers solved the case of the constitution in the most convenient way for them, none of them being willing to lose any of their power. By canceling the term 'provisional' from the constitution wherever it could be found, and addressing Abu Dhabi, which has been the administrative center of the country ever since the creation of the United Arab Emirates in late 1971 as capital, the Supreme Council declared, on 20 May 1996, the provisional constitution to be, from then on, permanent. On 18 June 1996, the Federal National Council endorsed this historic step. ${ }^{54}$

50

51

52

53

54

Ibid., pp. 412-414. 


\section{The Relationship between Federal and Local Government}

The powers of the various federal institutions and their relationship with the separate institutions in each emirate, laid down in the constitution, have evolved and changed since the establishment of the state. Under the terms of the constitution, rulers may, if they wish, relinquish certain areas of authority, prescribed as being the responsibility of individual emirates, to the federal government, one such decision being that to unify the armed forces, as mentioned above, in the mid-1970s.

The constitution also permitted each emirate to retain, or take up membership in the Organisation of Petroleum Exporting Countries (OPEC) and the Organisation of Arab Petroleum Exporting Countries (OAPEC), although none have done so. The only emirate to be a member in 1971, Abu Dhabi, having chosen to relinquish its membership in favor of the Federation.

Over the course of the years since the Federation was created, the United Arab Emirates has grown vastly in all fields, those being for example the organs of government and the population. In general, smaller emirates have benefited more from these developments in different ways. Each emirate also has its own local institutions of government, whose nature differs in size and complexity from emirate to emirate, depending on a variety of factors such as population, area, and degree of growth. These new systems of government have not replaced the traditional forms, as discussed above, which coexist and evolve alongside them. ${ }^{55}$

\section{Local Government of the Emirate of Abu Dhabi}

With approximately 73,500 square kilometers the largest and most populous emirate, Abu Dhabi, has its own central governing organ, the Executive Council, chaired by the Crown Prince of the emirate, Khalifa b. Zāyid Āl Nahayyān ${ }^{56}$. It is divided into two regions, the Eastern and Western, both headed by an official with the title of Ruler's Representative. There is also a Ruler's Representative on the important oil terminal island of Dās. The main cities, Abu Dhabi and Al Ain, the latter also the capital of the Eastern Region and the foremost being since 1996 the official capital of the United Arab Emirates, are administered by Municipalities, each of which has a nominated Municipal Council; while the National Consultative Council undertakes a role similar to that of the Federal National Council on a country-wide level.

Ibrahim Al Abed / Peter Hellyer / Paula Vine (eds.), op.cit., pp. 37, 39 and Ministry of Informa56 tion and Culture, United Arab Emirates, op.cit., p. 18.

Situation covered until end of June 1998. 
Administration in this emirate is implemented by a number of local departments, covering topics such as public works, water and electricity, finance, customs, and organization and management. Some have a responsibility for the whole of the emirate, although in certain spheres, such as water and electricity, there are also departments covering only the Eastern Region. $^{57}$

\section{National Consultative Council (al-madilis al-istishāāī al-watan̄̄)}

On 1 July 1971 the ruler of the Emirate of Abu Dhabi signed the Act No. 2 of 1971 for instituting the National Consultative Council. His son, the deputy ruler of this emirate, ratified the Royal Decree No. 39 of 1972 as a bylaw for the Council on 10 September 1972.

\section{The National Consultative Council Act No. 2 for 1971 and its Subsequent Amendments}

We, Zayed bin Sultan ${ }^{58}$, Ruler of Abu Dhabi promulgate the following act:

Article 1

A National Consultative Council shall be formed to assist the ruler and the Executive Council of the Emirate of Abu Dhabi to perform their task, which shall consist of notable persons of the country and prudents and of those who have rendered distinguished services of Abu Dhabi nationals and original nationals of Arabian Gulf Emirates.

\section{Article 2}

Members of the Council shall not exceed more than fifty-five members. 59

Article 3

The ruler shall select the members of the Council, appoint them and accept their resignation by Emiri decree. Members of the first National Consultative Council are appointed within a period not exceeding two months from the date of conforcement [!] of this act.

\section{Article 4}

The period of membership in the Council shall be two years, renewable, which commences from the date of the first meeting.

It is permitted to re-select a member whose membership term has expired.

Article 5

Combination of National Consultative Council membership and any of the public of fice including department heads positions shall not be permitted.

Günter Barthel / Kristina Stock (eds.), Lexikon Arabische Welt, Kultur, Lebensweise, Wirtschaft, Politik und Natur im Nahen Osten und Nordafrika, Wiesbaden 1994, p. 13 and Ibrahim Al Abed I Peter Hellyer / Paula Vine (eds.), op.cit., p. 38.

In the of ficial English translation: Article 2 amended by Act No. 1 for 1990. 


\section{Article 6}

The Executive Council of the Emirate of Abu Dhabi shall bring before the National Consultative Council, the draft laws during its meeting for discussions and presentation of recommendations with respect thereof to the Executive Council for onward submission before the ruler for approval and promulgation.

The Council in its first session shall be notified of the acts promulgated in non-convention period.

\section{Article 7}

The Executive Council of the Emirate of Abu Dhabi shall notify the National Consultative Council with the treaties and agreements which are held with the other countries and different intermational organisations substantiated by expedient statement.

\section{Article 8}

The National Consultative Council shall discuss any of the public subjects, related to the affairs of the country in presence of competent department heads and shall express wishes and recommendation to the ruler or the Executive Council of the Emirate of Abu Dhabi and shall give reply to the chairman of the department with respect to questions put forward by the members of Council regarding the intemal matters within its jurisdiction as per the procedures stated in the Council bylaw.

\section{Article 9}

The National Consultative Council shall produce its recommendations to the Executive Council of the Emirate of Abu Dhabi with respect to all the matters referred thereto within a period of not more than one month.

\section{Article 10}

The National Consultative Council member, shall take an oath before assuming his duties in the Council as follows:

"I swear by the Almighty God to be loyal to the country and the ruler and shall respect the rules of the country and seek welfare and progress and carry out my works in the Council loyally, sincerely and God witness so."

\section{Article 11}

The place of the member shall be regarded as vacant in the following cases:

1. On his death.

2. On his resignation.

3. If he is convicted for a crime against honour.

\section{Article 12}

If the place of any member shall become vacant before the end of his membership due to any reason, the ruler shall appoint his successor within two months from the date when the Council declares the of fice vacant, unless the vacancy lies during the previous three months, before the end of the Council term. The new member shall complete the period of his predecessor.

\section{Article 13}

The Council shall convene its sessions in the capital and sessions may be convened in any other place if the convening decree so provides. 


\section{Article $14^{60}$}

The Council shall have an annual ordinary session which shall not be less than eight months, commencing in the first week of November every year. Extraordinary sessions may be called if necessary.

\section{Article 15}

Convocation and conclusion of the session shall take place by Emiri decree and any meeting convened contrary to that or in a place other than the legal place of meeting shall be regarded as invalid.

\section{Article 16}

The ruler or his delegate shall open the annual ordinary session of the Council and deliver a speech which includes situations of the country, the most important incidents and general affairs which took place during the year, and whatever the government intends to carry out with respect to projects and remedial works, during the new session.

The National Consultative Council shall select a committee from among its members to prepare the draft reply on the inaugural address including the comments of Council, and its aspiration. The reply shall be presented after approval by the National Consultative Council to the Executive Council of the Emirate of Abu Dhabi to be submitted to the ruler.

\section{Article 17}

The members of the Council shall not be blamed with respect to what they express of utterances, opinions while performing their work within the Council or its committees.

$$
\text { Article } 17 \text { repeated }^{61}
$$

It is not permissible during the session, other than flagrante delicto to take penal action against any member without the permission of the Council. In the event of taking such procedures in the absence of Council, the Council should be apprised with as given in the Council bylaw.

\section{Article 18}

The chairman and members of the Council shall be entitled to remuneration determined by the law from the date of taking the oath.

$$
\text { Article } 19^{62}
$$

The Council in its first session of its legislative term, shall elect by secret ballot, a chairman and deputy chairman as per the rules and procedures stipulated in the Council bylaw. The office term of chairman and his deputy shall expire by the end of membership period in the Council or by dissolving as per rules this act.

\section{Article 20}

The Council shall lay down its bylaw which shall be promulgated by a Royal decree. The bylaw determines the powers of the chairman and his deputy and in general, whatever is related to Council affairs, committees, members, general secretariat staff, and the manner of the performance of their tasks, rules, procedures of discussions, voting, committees and others within the limit of this act.

60

In the of ficial English translation: Article 14 amended by Act No. 2 for 1980

61 62

In the of ficial English translation: Article 17 repeated as per Act 2 for 1980.

In the official English translation: Article 19 amended by Act No. 2 for 1980. 
Article 21

Sessions of the Council are convened openly. Sessions may be convened behind closed doors if one of the department heads, the chairman of the Council or at least one third of its members so request.

Article 22

Meetings of the Council may be adjourned by Emiri decree for a period, not exceeding one month. It is also permitted by an Emiri decree to dissolve the Council, provided the dissolving decree shall include convocation of the new Council to be concemed in a period which not exceed sixty days from the date of the dissolving decree.

The new Council may not be re-dissolved for the same reason.

This act shall come into force with effect from the date of signature thereon.

Issued at our court in Abu Dhabi

This 8.5.1391 A.H.

Corresponding to 1.7 .1971 . $^{64}$

Zayed bin Sultan Al Nahyan, ${ }^{63}$

Ruler of Abu Dhabi

Royal Decree No. 39 for 1972

Ref.: Bylaw of the National Consultative Council and its Amendments

We, Khalifa bin Zayed Al Nahyan, ${ }^{65}$ Deputy Ruler of Abu Dhabi.

Pursuant to the authorities rested in us by H.H. father Zayed bin Sultan Al Nahyan ${ }^{66}$ the Ruler of Abu

Dhabi.

In conformity with the rules of Article 20 of the National Consultative Council Act No. 2 of 1971 and in according the proposal of the chairman of the National Consultative Council and approved by the Executive Council.

Promulgate the following decree:

\section{Chapter One - Organising of the Council}

\section{Section 1: Formation of the Council and the Rules of Membership}

Article 1

The National Consultative Council is formed by a number of members not exceeding fifty-five to be selected by the ruler.

Article 2

The member of the Council shall be a national of Abu Dhabi and of good opinion and of original nationals of Arabian Gulf Emirates who have rendered distinguished services to the country.

63

64 See footnote 58

(National Consultative Council), Rules and Regulations of the National Consultative Council. [Abu Dhabi] 1995, pp. 1-5. For the Arabic text see the same book, which contains both text versions.

(Al-Madjlilis al-Istishhārī al-Watānī), Al-ḳānūn wa-'l-niẓām al-dākhilī li-'l-madjlis al-istishāāī alwațani. [Abū Zabī] 1995, pp. 1-5.

65

According to the transcription of $E I^{2}$ : Khalifa b. Zāyid Āl Nahayyān.

66

See footnote 58 . 


\section{Article 3}

The member of the Council during the term of his membership shall not be allowed to combine his membership and any public office including department heads positions.

Article 4

A member in the Council who combines membership and any public office, has to select one of them during the eight days following the case of combination, otherwise he shall be deemed to have selected the latest one.

Such member shall be entitled only to the pay or remuneration of the of fice finally selected for the period proceeding selection.

\section{Article 5}

Duration of membership in the Council is two calendar years commencing from the date of the first meeting thereof. Those whose membership has expired from the Council may be re-elected.

\section{Article 6}

The member of Council shall before assuming his work in the Council and its committees, take an oath saying:

"I swear by the Almighty God to be loyal to the country and the ruler and shall respect its laws and seek for the welfare and progress of the country and carry out my tasks in the Council sincerely and loyally. God so witnesses."

\section{Article 7}

The Council shall convene its sessions in the capital.

Excluding from the above paragraph the Council shall have the right to hold its sessions in any other place if it is stated in the promulgated decree of the convention and each meeting convened by the Council in another place and dates as determined for meeting shall be regarded as null and void, hence the resolutions resulting accordingly shall also be null and void.

\section{Article 8}

The member of the Council has the right to resign, and the resignation shall be submitted in writing to the chairman of the Council and shall be presented before the Council in its first session following its submission. The resigning member has the right to draw back his resignation before the resolution of the Council is passed with respect thereof. Resignation should be approved by a Royal decree.

\section{Article 9}

If the office of the member becomes vacant due to his death, resignation or condemnation of a crime affecting his honour, the chairman of the Council shall declare that, and has to notify the ruler within one week at the latest for selection of another member within two months from the date of declaration by the Council of such vacancy unless, the vacancy lies during the previous three months, before the end of the Council term.

The new member shall then complete the period of his predecessor.

\section{Article 10}

The member of the Council shall be at liberty to express statements and opinions while performing his duties in the Council or its committees and under no circumstances shall he be blamed for that. 


\section{Article 10 repeated $1^{67}$}

It is not permissible, during Council session, other than in case of flagrante delicto to take action of interrogation, inspection, arresting, imprisonment, or any penal action against any member without permission of the Council, and in case of such an act, the Council shall be notified of any penal action which may be taken during its session.

The Council should in its next meeting be notified of any penal action taken in absence against any one of its members. Such action should obtain the Council's permission if it continues. In all cases, if the Council shall not decide upon the request for permission within one month from date of receipt thereof this shall be deemed a permission.

Article 10 repeated $2^{68}$

The permission request for lifting immunity from the member shall be submitted to the chairman of the Council by the Minister of Justice or by those who intend to lodge cases against the member in the penal courts. The request should be accompanied with the case papers for which the penal action is required therein, or official photocopy of the indictment along with the substantiating documents, if the request is submitted by an individual. The chairman of the Council shall refer the said request to a legislative and legal committee for discussion and submission of a report accordingly to the Council. Hearing of such requests shall be before the committee and Council depending on its urgency.

\section{Article 11}

The member who fails to attend one of the session has to notify the chairman of the Council with reasons of non attendance.

In case he shall be constrained to remain absent for more than one month, he should obtain the permission of the chairman. It is not allowed for the member to request an unlimited leave.

The member who was present in the session shall not be allowed to leave it decisively before it is over except by permission of the chairman.

\section{Article 12}

If the absence of member in one term is repeated for five consecutive sessions without an acceptable excuse, or in ten consecutive sessions, his membership funds will be stopped for the period of absence.

\section{Article 13}

If the member fails to attend the committee sessions for three consecutive times without excuse, the committee by majority may consider the member as resigned and shall inform the Council accordingly in the first following session so that another member shall be elected.

\section{Article 14}

The member shall not be allowed to interfere in any act of the judicial and executive powers.

67

Footnote of the official English translation: Article 10 repeated 1 and Article 10 repeated 2 (by mistake written, ... and Article 11 repeated ...) are added by Royal Decree 3 of 1980.

68 In the of ficial English translation: No further note but see footnote 67 


\section{Section $^{69}$ 2: Council Chairmanship and Secretariat}

Article 15

The Council shall in its first session of legislative term elect the chairman and deputy chairman from among its members. Election in all cases shall be secret and by the absolute majority of its present members.

If such a majority is not achieved the first time, election shall be made again between the two who hold the majority of votes.

If anyone else has become equal with the second one in the number of votes, then he shall take part with them in the second election.

Election in this case shall be by relative majority. If more than one becomes equal in gaining the relative majority, the election shall be through ballot.

The eldest among the members shall preside over the first session until the chairman is elected.

$$
\text { Article } 16^{70}
$$

In the event where the post of chairman or his deputy becomes vacant due to any reason, the Council shall choose in the manner stated in the above article his successor in the first session which follows the vacancy if the Council is in session.

If the vacancy shall take place during the Council holiday, the election shall be made during the first week of the Council meeting.

Tenure of each of the chairman and his deputy shall expire by expiry date of membership in the Council or by dissolving according to Articles 4 and 22 of the Act No. 2 of 1971 ref. the National Consultative Council.

\section{Article 17}

The chairman represents the Council in its contacts with the other bodies, talks in its name and supervises all its works and oversees its committees. He also oversees the general secretariat of the Council and has to observe and implement the acts and put in action the provision of this bylaw.

The chairman shall in particular assume the following duties:

a. Discipline keeping inside the Council and give orders to the private guards of the Council, the chairman may seek help from the police if necessary.

b. Presiding over the session, giving permission for talks, organising the discussion, taking votes and declaring the resolutions of Council.

c. Preparation of Council balance sheets and final accounts and have them brought before the financial committee for examination, then to the Council for approval.

d. Signing the contract in the name of the Council.

e. Exercising the powers, legally vested in the department head with respect to the Council staff.

f. Drawing up the system of visitors who attend the session and has the right to give order to expel the visitor if he talks in the session or if he expresses approval or disapproval by any form and taking legal actions against him (if any).

\section{Article 18}

If the chairman remains absent, his deputy shall hold the of fice and, if the latter remains absent, the chairmanship shall be vested in the eldest member present.

In the publication there is an error: Chapter.

70

In the of ficial English translation: No further note. 
The chairman has the right at the time of his absence to empower his deputy with all or part of his powers if the deputy is not absent.

The deputy shall stand instead of the chairman in all his powers if the chairman remains absent for more than four consecutive weeks.

\section{Article 19}

The general secretariat and legal department of the Council are organised by a resolution passed by the chairman of the Council. Such a resolution shall include the detailed rules related to administration, finance and legal affairs.

The general secretariat is presided over by a secretary-general and the legal department shall be presided over by the legal advisor who both shall be appointed by a Royal decree as per nomination by the chairman of the Council.

The rules and regulations of civil service shall be applied to the Council employees and servants in this respect.

\section{Article 20}

The secretary-general shall be responsible for the general secretariat and its employees affairs before the chairman and shall attend the Council ordinary sessions. He shall have the right by approval of the Council to attend the secret session. He shall also attend the sessions of committees if the committee so requests.

The secretary-general shall with respect to Council employees have the same powers given by the rules and regulations for the department undersecretary in respect is the affairs of his department and staff. The legal advisor shall give his legal opinion on the matters referred to him by the chairman or the Council or its committees. He shall attend the Council/committee sessions whenever he is required to do so, and shall be responsible for the work of the legal department before the chairman of the Council.

\section{Article 21}

In the event of dissolution the general secretariat and the bodies of the Council shall be attached to the Executive Council of the Emirate of Abu Dhabi.

\section{Article 22}

The Council shall form the following permanent committees:

1. Internal Affairs and Defence committee consisting of eight members.

2. Finance, Economic, Industry, Commerce, and Petroleum committee consisting of eight members.

3. Legislative and Legal Affairs committee consisting of eight members.

4. Education, Agricultural Information and Affairs committee consisting of eight members.

5. Health, Labour and Social Affairs committee consisting of eight members.

6. Municipality and Public Utilities committee consisting of eight members.

In case any subject is associated with more than one committee the Council shall determine the committee which shall see it or refer it to a joint committee which shall include more than one committee according to this bylaw.

\section{Article 23}

The Council shall have the right to form other permanent or temporary committees according to the work exigencies and shall pass a rule to each committee to serve the purpose. 
Article 24

The Council shall elect the committees' members by relative majority and each member should take part at least in one committee. It is not allowed for the member to participate in more than two permanent committees.

Article 25

Each committee shall elect from among its members a chairman and rapporteur and shall have a secretary elected from Council employees. In the event of absence of the head of the committee, the rapporteur shall substitute him with the same powers and if both of them are absent the eldest of the present members shall assume the of fice. The chairman of the Council shall call the committees for meetings until their heads are elected.

\section{Article 26}

The rapporteur shall recite the report of the committee in the Council and pursue discussion thereof. The committee may choose a rapporteur for a specified subject to work with the permanent rapporteur or to perform for such particular subject.

The committee may seek the help of one or more of the Council experts or its employees and may request through the chairman of the Council to seek help from one or more government experts or employees. Such shall not be allowed to participate in voting.

\section{Article 27}

The sessions of the committees are secret and are convened in the presence of the absolute majority of its members. The minutes of the meeting shall be drawn up where the discussions are briefed therein and resolutions are written down and signed by the head of committee and its rapporteur.

Each member of the Council has the right to attend the sessions of the committee in which he is not a member, provided he obtains approval of the committee and provided that he shall neither interfere in discussion nor make comments.

Each member has the right to see the committee's minutes of meetings.

\section{Article 28}

The Council committees may through the chairman request the departments, public corporations, and bodies for information and documents deemed necessary for studying the subject referred thereto, and such authorities must present the required information and documents in order to be examined by the committee a sufficient time before making its report.

\section{Article 29}

Draft laws and papers shall be distributed to the members at least three days prior to the convention of the committee session. This period shall be reduced to twenty hours in the event of expedition.

Article 30

Department heads shall have the right to attend the session of committees at the time of hearing a subject related to their departments and they may be accompanied by one or more competent senior staff or experts or delegate any of them.

The department head, his companion of delegate shall not have a vote in the committee deliberations but their opinion only shall be entered in the report.

The committee may through the Council chairman request the presence of the head of department for discussing the matter. In such cases the head of department or his delegate should attend according to the above paragraph. 


\section{Article 31}

Committees shall be convened as per convocation by their heads or by the chairman of the Council. They shall convene if the majority of members so request.

Convocation of the committee shall be at least twenty-four hours prior to its time of convening. The session agenda shall be sent to the members.

\section{Article 32}

The adjourning of the Council sessions shall not preclude the convening of committees to perform their outstanding work, and the chairman of the Council may convoke committees for meeting in between the sessions if he deems fit or at the request of the Executive Council or the head of the committee.

\section{Article 33}

The committees that participate in discussing one subject hence, shall hold joint meetings approved by the chairman of the Council. In this case the head of the committee and its reporter shall be the eldest of the members.

For the validity of joint meeting, the majority of members of each committee should be present at least separately. Resolutions are passed by the majority of members present in the session.

\section{Article 34}

The committee shall submit to the chairman of the Council a report on every subject referred thereto, under which its work and recommendations shall be stated therein briefly. Within two weeks from the date referring of the subject thereto the Council shall grant the committee a new respite or shall refer the subject to another committee if submission of the report in non-fixed time has been reiterated in delay. The Council may pass decision on the subject without waiting for the report of the committee.

\section{Article 35}

The committee report shall include the draft law initially proposed the bill ratified by the committee and the reasons on which their opinion was based. It should also include the minority views. Committees' reports are distributed to members of the Council along with the agenda.

\section{Chapter Two \\ Section 1: Meeting of the Council \\ Article $36^{71}$}

The Council shall sit an annual ordinary term of not less than eight months, commencing in the first week of November every year.

\section{Article 37}

The Council shall convene its ordinary term upon a convocation by Royal decree.

\section{Article 38}

The Council is convoked for extraordinary meeting by Royal decree if necessary.

The Council is not permitted at the extraordinary convention term to view other matters than those it has been called for.

Article 39

A Royal decree shall be issued for a rise of ordinary and extraordinary convention terms.

71

In the of ficial English translation: No further note. 
Article 40

The adjourning of the meetings of the Council for a period not exceeding one month is permitted under a Royal decree and the adjournment period is not counted within the period of the Council's ordinary term.

Article 41

The Council convenes ordinary sessions on the first Monday of every fortnight unless the Council decides otherwise of if there are no works which necessitate meeting.

Article 42

The chairman of the Council shall prepare the agenda of sessions, declare it and inform the members and the general secretariat of the Executive Council at least three days prior to the meeting.

The chairman may convoke the Council for a meeting prior to its ordinary date if necessary. He should convoke if the government or at least twenty members so request. The convocation shall fix the subject to be discussed.

Article 43

Sessions of the Council shall be public, and they may be convened secretly at the request of department heads, the chairman of the Council or at least one third of its members. The request shall be discussed in closed door sessions.

\section{Article 44}

At the time of convention of a secret session, all the auditoriums and terraces shall be vacated of those permitted entry and no one other than members shall be allowed to attend the session.

The Council shall select the appropriate person to write down the minutes of the secret sessions. The minutes shall be maintained by the chairman of the Council. No one other than members or those allowed to attend the session is permitted to see the minutes.

The session shall be reinstated to be held in public by a resolution of the Council if the reason of secrecy ceases to exist.

\section{Section $^{72}$ 2: System of Work in the Sessions}

Article 45

Half an hour before the opening of the session. attendance books shall be placed at the members disposal in order to sign therein when they attend the session.

\section{Article 46}

The chairman shall declare the opening of Council sessions if the majority of its members are present. If the appointment lapses while the quorum has not attended the chairman shall hold up opening of the session for one hour, and if the quorum is not complete, the chairman shall announce adjournment of the session due to non completion of quorum.

\section{Article 47}

After the opening of the session the secretary-general or his representative shall recite the names of the apologizing members and absentee members, then the opinion of the Council shall be taken to ratify

In the publication there is an error: Chapter. This error of translation is caused by a typing error in the Arabic text writing 'bāb' instead of 'fașl'. 
the minutes of previous session. The chairman shall inform the Council of the papers and letters received before discussion of the matters on the agenda.

\section{Article 48}

The deliberations of Council shall be regarded valid unless the majority of members are present. Resolutions are passed by absolute majority of the present members in the cases other than which require a special majority. In case of equalization of votes, the side of the session supported by the chairman shall prevail.

\section{Article 49}

No person shall be allowed to talk without permission of the chairman. The chairman shall not prevent any person from talking without a legal justification. When differences arise the Council shall decide upon the matter.

\section{Article 50}

Interruption of the speaker is not permitted and discussion of private matters is also not permitted. The chairman shall have the right to prevent the member from talking lengthily and shall refer the matter to the Council for decision.

\section{Article 51}

It is always allowed to speak in the following cases:

a. Drawing the attention to observe the rules of Council bylaws.

b. The reply to a statement which affects the person seeking to speak.

c. Request to postpone, or defer reviewing of the subject presented for discussion after making decision on other subject which ought to be decided in the first place.

d. Request for closing the discussions.

Such requests according to their order shall have priority on the original subject, which results in stopping the discussion thereof until the Council passes the relevant resolutions.

\section{Article 52}

According to a proposal made by the chairman of the Council, the Executive Council, the competent committee or upon a request in writing submitted by at least five members may fix a time for the closing of discussion of subjects and taking view thereon or the closing of discussion.

\section{Article 53}

The speaker shall talk while standing or on the platform and the reporters shall talk on the platform unless the chairman shall order otherwise.

\section{Article 54}

The chairman solely shall have the right to draw the attention of the speaker to observe the rules of bylaw and respect the rules of speech and its subject.

If the chairman draws the attention of the speaker twice in one session and the speaker repeats the cause in the same session, then the chairman shall have the right to propose to the Council to prevent him from talking on the same subject until the end of session. The resolution of Council shall be issued without discussion.

\section{Article 55}

The use of unsuitable terms which may effect persons or bodies or cause damage to high interests, and also the violating of discipline is not permitted. If the speaker does so, the chairman shall draw his attention to the matter. If differences arise, the Council shall decide the matter without discussion. 


\section{Article 56}

The Council shall impose one of the following penalties on the member who breaches discipline or does not abide by the resolution of the Council for preventing him from talking:

a. Notice.

b. Blame.

c. Preventing the member from speaking until the end of the session.

d. Taking him out of the conference room and depriving him from participating until the end of the session.

e. From future participation in the Council works and its committees for two consecutive sessions. A resolution by the Council is passed in this respect on the same session. The Council may stop the resolution passed against the member if the latter submits his apology in writing.

Article 57

If the discipline is disturbed in the session and the chairman fails to restore it, he shall announce his intention to stop the session. If the discipline has not been restored, he shall suspend the session for a period not exceeding half an hour.

If discipline continues to be disturbed after restoring the session, the chairman may adjoum the meeting.

Article 58

The chairman may temporarily adjourn the session for a rest for a period not exceeding half an hour.

\section{Section 3: Minutes of Meetings}

Article 59

The minutes of the meeting shall be assigned for each session wherein all the procedures of the session and subjects presented, discussions, resolutions, names of members in each ballot made by roll-call shall be recorded in detail.

Article 60

Each member present at the meeting has the right to request making the correction on ratifying the minutes of the meeting.

When the resolution is passed by the Council for acceptance of the correction, this shall be listed in the respective minutes, and the earlier minutes shall be corrected accordingly.

Asking for any correction in the minutes after ratification is not permitted.

Ratification of the final minutes of the meeting in the convention term or legislative period shall be executed by the chairman of the Council.

Article 61

The chairman of the Council and secretary-general shall sign the minutes of the meeting after ratification which shall be kept in the Council records.

Article 62

A summary of the minutes of the meeting shall be made ready after each session, wherein the subjects which were brought before the Council for discussion, and the actions taken shall be stated in order that they be within access of local publication organizations. 
Article 63

The chairman has the right to order excluding from the minutes of the meeting any expressions originated by one member against the rules of this bylaw.

On objection, the matter shall be brought before the Council and his resolution shall be passed in this respect without any discussion.

\section{Chapter Three - Capacities of the Council}

Article 64

The chairman shall present to the Council the draft laws, submitted by the Executive Council of the Emirate of Abu Dhabi to refer them to competent committees unless the Executive Council of the Emirate of Abu Dhabi requests consideration of the draft law urgently, or if the chairman deems it urgent, stating the reason, and then he shall refer it directly to the competent committee and inform the Council in next session. The draft law shall be distributed to members along with the agenda.

Article 65

If the draft laws on one subject have become numerous, the earliest should be regarded as the original and others deemed to be as amendments thereto.

If the competent committee has introduced amendments on the draft law, it shall have the right prior to bringing its report before the Council to refer it to a legislative/legal committee to give opinion on the wording of draft law, co-ordinate its clauses, and the committee has to point out in its report the opinion of the legal and legislative committee.

Article 66

Discussion of draft laws starts with reciting the original draft law and its explanatory memo, the report of the competent committee and its amendments, then the order shall be given to discuss the draft law by the reporter of the committee, then to the Executive Council, then to the members.

If the Council approves the draft law in principle it shall discuss its articles one by one after the reciting of each as well as the proposals submitted in this regard. Opinions then shall be taken on each article then on the draft law as a whole.

\section{Article 67}

Each member during the discussing of the draft law may propose amendments, omissions or the splitting of articles. Amendments should be submitted in writing twenty-four hours prior to the session wherein the articles included in the amendment shall be discussed.

It is also permitted by approval of the Council to review and consider the amendment which is submitted during the session, and resolution of the Council shall be passed after hearing the clarification of the proposer and without discussion. The Council also has the right to refer any amendment introduced on draft law to the legal and legislative committee to express its view on formulation and co-ordination of its rules.

Discussion of the draft law thereafter shall be limited to formulation.

Article 68

The competent committee shall in all circumstances be notified of the amendments submitted by the members prior to the fixed session, which is scheduled for viewing and consideration of the draft law by the Council. The reporter shall state the opinion of the committee therein during the discussion at the session. 


\section{Article 69}

Proposal of amendment should be specific and formulated. The Executive Council and the reporter of the concermed committee may request referral of the proposed amendment to the committee. The request should be responded to unless the amendment proposed has not already been presented to the committee.

\section{Article 70}

After completing the discussion the article and amendment submitted in connection therewith, opinions shall be taken in the first place and the chairman shall start with the most extensive one which is farf rom original text then he shall seek the opinion on the article in whole.

\section{Article 71}

If the Council decides on an article which necessitates making amendment to an article already approved, the Council shall move to discuss that article.

The Council may, at the request of the Executive Council or the committee or any of the members decide to re-discuss an article already decided if new reasons are expressed before closing the deliberation of the draft law.

\section{Article 72}

If the proposed amendment shall affect the rest of the draft law articles, consideration thereof shall be adjoumed until the committee finalizes work on it, otherwise the Council shall continue discussing the remaining articles.

The amendments shall be deemed as non-existent and shall not be proposed for discussion if abanded by proposers without being adopted by one of the members.

\section{Article 73}

The taking of opinions on the draft law shall be in public by raising hands. If the majority cannot be decided, the opinions shall be taken by calling out the names of the members.

Opinion on voting by roll-call shall be taken in the following cases:

a. Draft laws.

b. Cases requiring a particular majority.

c. In case the Executive Council, the chairman or the then members at least so request.

In exceptional cases and under approval of the Council the voting may be made secret at the request of those mentioned in "c" above.

In all cases the chairman shall cast his vote after all members.

\section{Article 74}

The Council shall vote on draft laws for approval, rejection or amendment. Refusal or amendment shall be only by majority of members of the Council.

The recommendations of the Council shall be submitted to the Executive Council of the Emirate of Abu Dhabi for onward submission to the ruler for approval and promulgation.

\section{Article 75}

The chairman shall notify the Council of the treaties and the international agreements supported by government declaration. Such declaration shall be recited in the next session. Treaties and their enclosures shall be deposited with the secretariat of the Council. The Council may express comments on treaties without taking decisions with respect to the treaties themselves. 
Article 76

According to a request signed by five members a common subject may be brought before the Council for discussion, inquiry about the Executive Council policy on it and the exchanging of views.

All members have the right to take part in discussion. The Council shall issue its recommendations in connection thereof which shall be presented to the Executive Council.

Article 77

The chairman of the Council shall notify the chairman of the Executive Council of the Emirate of Abu Dhabi of the discussion request right after submission. If the Executive Council shall advise the National Consultative Council that discussion of that subject is against the high interest of the country, the chairman shall not have it enlisted in the Council agenda; but if the Executive Council shall not express any objection, the Council thereafter may refer it to one of the committees for discussion and the making of a report there before the decision is made final.

The recommendations of the Council shall be submitted in this respect to the Executive Council within one month.

\section{Article 78}

If applicants abandon their request or absent themselves from the session scheduled for consideration thereof, five of the Council's members shall be permitted to adopt it, and the Council shall continue consideration thereof, otherwise it shall be eliminated from the agenda.

\section{Article 79}

Each member has the right to put questions to the chairman of the Executive Council and department heads for inquiry about internal matters falling within their capacities, including questions about a matter which the member is not aware of, or the verification of an occurrence which he has become aware of. The addressing of questions should be made by only one member and shall be addressed to the chairman of the Executive Council or to one of the department heads.

\section{Article 80}

The question should be signed by the applicant and, as much as possible, should be written clearly and briefly, and should be limited to matters subject to the inquiry without any comments and without unfit expressions which may affect persons or bodies or which may cause damage to the high interests of the country. If the question causes the foregoing conditions, the chairman of the Council shall eliminate it.

If the member is not convinced of the chairman's view, the matter shall be brought before the Council for final decision without any discussion.

\section{Article 81}

The chairman of the Council shall convey the submitted question according to the above article, to the chairman of the Executive Council or to the concerned department head and it shall be included in the next session agenda following the date of notification to the chairman of the Executive Council or the department head.

\section{Article 82}

The chairman of the Executive Council or the concerned department head shall answer the question in the session scheduled for its consideration. The chairman of the Executive Council or the competent department head have the right to defer the answer to a date not exceeding two weeks. Deferment for more than this period shall be only by resolution passed by the Council. 
The chairnan of the Executive Council or the competent department head may deposit the answer or required information with the general secretariat of the Council for viewing by the members and this shall be noted down in the minutes of the meeting.

\section{Article 83}

The member making the question solely shall have the right to comment on the reply. The comments should be made brief and only once.

\section{Article 84}

The Executive Council may of its own accord or on occasion of a question addressed thereto, request discussion of a specific subject related to the affairs of the country, to obtain the recommendation of the Council or to deliver its statements in this regard.

\section{Article 85}

If the inquirer withdraws his question, any member shall have the right to adopt such question, and in this case the Council shall continue consideration thereof, otherwise discussion shall be eliminated.

\section{Article 86}

The answers on the questions addressed to the chairman of the Executive Council or the department heads during its sessions shall be made in writing to the chairman of the Council which in turn, shall be conveyed to the members who put forth such question. The reply shall not be bound to the dates specified in the above articles and shall be enlisted in the agenda of first forthcoming session.

\section{Article 87}

The question shall be abated by the expiry of membership of the inquirer for any other reason unless another member adopts such question, hence the Council shall consider it.

\section{Article 88}

The Council shall approve its annual budget within the funds approved for the emirate in agreement with the Executive Council.

The rules of the emirate's budget shall apply to the Council budget.

\section{Article 89}

The funds allocated to the Council shall be deposited in the emirate budget in the place where the chairman of the Council chooses. Payment shall only be made by permission of the chairman of the Council or his representative.

\section{Article 90}

After the end of the fiscal year, the general secretariat of the Council prepares the final accounts and the chairman shall refer the same to the financial committee to examine it before bringing it to the Council for discussions and approval.

The same procedures for ratification and issuance of the final accounts of the emirate shall apply to the final account of the Council.

\section{Article 91}

All petitions, complaints submitted to the Council should be signed by applicants and should be void of any unsuitable words otherwise the chairman may order to drop them. 


\section{Article 92}

The chairman of the Council shall refer the petitions and complaints submitted to the Council to a competent committee and the Council shall be notified of the same in the first forthcoming session of the Council.

The Council and the committee as well have the right to ask the competent authorities to submit clarification of such petitions and complaints. Such authorities shall submit the required clarifications within two weeks at most, unless the Council decides otherwise.

\section{Article 93}

Urgent subjects shall first be discussed by the Council and its committees and the rules of determined appointments shall not apply thereto herein. The Council shall decide the discussing of urgent subjects in the same session, provided the competent committee submits its report to the Council in the session. The subject shall be deemed urgent if the Executive Council of the Emirate of Abu Dhabi, the competent committee, the chairman of the Council or five members request so in a signed letter.

The budget or financial acts shall not be considered on an urgent basis.

\section{Article 94}

This decree shall come into force from the date of promulgation and shall be published in the official gazette.

Issued by us in the presidential palace

This 2.8.1392 A.H.

Corresponding to $10.9 .1972 .^{74}$
Khalifa bin Zayed Al Nahyan, ${ }^{73}$

Deputy Ruler of Abu Dhabi

Mohammed Habroosh,

Minister of State

Due to the latest available information ${ }^{76}$, the National Consultative Council has sixty members and not as stated in Article 2 of the Act No. 2, 1971 as well as in Article 1 of the Royal Decree No. 39, 1972, a membership not exceeding fifty-five. ${ }^{77}$

To assist the ruler and the Executive Council, the highest governing organ of the Emirate of Abu Dhabi, the National Consultative Council was formed. Its major activity is given to the debating of draft laws presented to it by the Executive Council. Although each member may propose amendment, omission or the splitting of articles at the stage of discussing the bills, only the recommendations of the Council can be submitted to the Executive Council for onward submission to the ruler for approval and promulgation. By law a member is not allowed to interfere in any act of judicial and executive powers. As in the case of the

73

74

75

76

77

See footnote 65 .

According to the transcription of $E I^{2}$, Muhammad Habrūsh.

(National Consultative Council), op.cit., pp. 6-32. The Arabic text see footnote 63. (Al-Madjlis al-Istishārī al-Wațanì, op.cit., pp. 6-27.

Situation covered until approx. mid-1997.

Ibrahim Al Abed / Peter Hellyer / Paula Vine (eds.), op.cit., p. 38. 
Federal National Council, the authority of the National Consultative Council is also very limited. This area is curbed in reality to a consultative one.

From what citizens of the United Arab Emirates say, the sittings of the National Consultative Council are much more frequent than those of the Federal National Council. According to the regulations the members of the National Consultative Council meet for the ordinary session on the first Monday of every fortnight during the annual term, unless the Council decides otherwise or if there are no duties which make a meeting necessary. The annual term as well as an extraordinary sitting have to be convoked by a Royal decree. Any session convened contrary to that or in a place other than the legal place of meeting is regarded as invalid and resolutions resulting accordingly are null and void. These stipulations are similar to those concerning the Federal National Council.

The members of the National Consultative Council are drawn from among the emirate's main tribes and families ${ }^{78}$ and original nationals of the Arabian Gulf Emirates as laid down in Article 1 of the Act No. 2, 1971 and Article 2 of the Royal Decree No. 39, 1972. It is a fact, that for example, the majority of the citizens of the city of Abu Dhabi are not originally from this emirate, but have received the nationality of the United Arab Emirates over the years. The selection of the Council's members is made by the ruler, deciding, who belongs to the notable persons and prudents of the emirate as well as those, who have rendered distinguished services to Abu Dhabi.

As for the Federal National Council, the period of membership in the National Consultative Council is also two calendar years, commencing from the date of the first sitting with the possibility of re-election.

A member of the Federal National Council as well as the National Consultative Council is not permitted to hold any public of fice during his membership. Regarding the National Consultative Council mention is made of this in Article 5 of the Act No. 2, 1971 and Article 3 of the Royal Decree No. 39, 1972.

\section{Facts on the Development of the National Consultative Council}

On 8 July 1971, the formation of the first National Consultative Council was reported and its first meeting took place on 3 October $1971 .^{79}$ The Executive Council approved on 24

78

79

Ibid.

Ibrahim Al Abed / Paula Vine / Abdullah Al Jabali (eds.), op.cit., p. 13 and [Imārat Abü Zabī?],

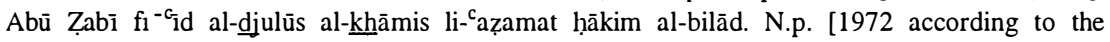
Libraries of the UAE University, Al Ain], p. 150. 
July 1972 the internal rules and regulations of the National Consultative Council and the Crown Prince Khalífa b. Zāyid Āl Nahayyān issued a decree formally establishing these provisions for the body on 26 September $1972 .^{80}$

The Council has, in accordance with Article 22 of the Royal Decree No. 39, 1972, six permanent committees, each of them consisting of eight members, dealing with all aspects of modern society. On the list of the first period of membership stated among the members are eight dignities, officially holding the title Sheikh. ${ }^{81}$ One of them, Sultān b. Surūr alZāharī was appointed chairman in the first elections of the body on 1 October 1972, who held this position until he passed away on 10 August $1990 .^{82}$ Official sources showed in the year $1995{ }^{\mathrm{C}}$ Abd Allāh Muhammad al-Mas ${ }^{\mathrm{c}} \overline{\mathrm{u}} \mathrm{d}$ in the position of chairman. ${ }^{83}$ At present the sittings of the National Consultative Council are held in a wing of the old fort of Abu Dhabi, called Al Husn Palace, which also houses the Centre for Documentation and Research in the central area of the city. It is planned to build a new complex for the Council in the near future.

Besides the debating of bills, approving the budget and the annual development schedule as well as being informed on matters regarding the Emirate of Abu Dhabi, ${ }^{85}$ the National Consultative Council itself occasionally gives statements and recommendations to affairs concerning not only the emirate, but the Federation in general and even subjects of international concern, as described in the following examples.

The National Consultative Council expressed on 8 December 1971 its strong condemnation of the occupation by Iranian forces of the two islands of Greater and Lesser Tunb belonging to Ras al-Khaimah. On 5 January 1972 the body advised that the telephone system in the country be subject to government administration similar to other public utilities such as water, electricity and communications. On 23 April 1975 the Council recommended a reconsideration of the agreement with CCC Company, owners of 40 per cent of the capital of the Abu Dhabi National Oil Installation Company, so that the shares could be offered to the public for general subscription. The body advised against the construction of official government office buildings in the middle of the capital Abu Dhabi to prevent overcrowding on 30 January $1996 .^{86}$

80

81

82

83

84

85

86

Ibrahim Al Abed / Paula Vine / Abdullah Al Jabali (eds.), op.cit., pp. 26, 30.

[Imārat Abü Zabī?], op.cit., pp. 147-150.

Ibid., p. 148 and Ibrahim Al Abed / Paula Vine / Abdullah Al Jabali (eds.), op.cit., pp. 30, 323.

(National Consultative Council), op.cit., illus.

Situation covered until end of March 1998.

See Ibrahim AlAbed / Paula Vine / Abdullah Al Jabali (eds.), op.cit., pp. 36, 97, 172.

Ibid., pp. 16, 17, 79, 406 and see also p. 14 f. as well as $E I^{2}$ Supplement Fasc. 5-6, p. 417 f. 
Two examples may show the interest in the National Consultative Council exhibited by Zāyid b. Sultān Āl Nahayyān, the Ruler of the Emirate of Abu Dhabi. On 31 October 1975 the members of the Council took the oath of of fice before the sovereign who told them, that he did not want a body who would act as a rubber-stamping institution: 'I want from you positive partnership in the service of the nation,' he said 'and I will not be lenient with those who dally with the nation's money'. In the opening speech of the Council's new session on 18 February 1990 the ruler said, that the body had played a positive rule in looking after the interests of citizens and in achieving their ambitions.

\section{Conclusion}

When the United Arab Emirates came into being as a state with local, regional, Arab and international dimensions, it was confronted with a combination of extremely difficult circumstances. During a relatively short period of time the country managed to complete its essential apparatus and establish those institutions vital to a state. It had been the desire of the rulers to start a democratic experiment, which culminated in the formation of both, the Federal National Council, ranging throughout the Federation and prior to that the National Consultative Council, covering the Emirate of Abu Dhabi only.

We have learned how the provisional constitution became a permanent one. There, the functions of the organ of popular representation are tailored to the requirements of the nascent state. Thus the rule of the forty members of the Federal National Council was envisaged to be generally of fostering and enhancing a growing sense of federal communal awareness. Many of the definitions in the constitution are too spongy or archaic.

By taking a close look at the chapter regarding the Federal National Council, we find, for example, such an ill-timed regulation in Article 70, Paragraph 4, where a member 'must have adequate knowledge of reading and writing'. Or the continuous possibility of a member's re-election as stated in Article 72. Would it not be of advantage for the Council in general, to permit a membership only for one further session or a maximum of two terms?

With regard to the obsolete regulation concerning the period of the first summoning of the Council, as mentioned in Article 78, it seems somewhat absurd that this was adhered to in the permanent constitution.

The Federal National Council's greatest weakness ever shown was the endorsement for the provisional constitution to being permanent, which gave this body a "puppet on a string"

Ibrahim Al Abed / Paula Vine / Abdullah Al Jabali (eds.), op.cit., pp. 87, 315. 
image within the country's authorities. An opportune constitution would have been a progressive step in the socio-political life of the United Arab Emirates and would have surmounted in all likelihood many obstacles.

The National Consultative Council, on the other side, exposed prior to the establishment of the Federal National Council interests in national and even international matters.

Some rules for this regional-wide body are too vague or superfluous. For instance, the stating of the exact time to display attendance books before the opening of the sitting, as stated in Article 45 of the Royal Decree of 1972, while it is generally accepted that Arabs have an odd sense of time. Article 50 gives the chairman the authority 'to prevent the member from talking lengthily.' Definition of a maximum speaker's time would be clear for everybody. What also seems strange in Article 53 is the mentioning of how and where the speaker and the reporter have to stand whilst speaking during a sitting.

However, both merely consultative bodies do not have the power to be instruments of persuasion and pressure over consolidating institutions in the country or the emirate respectively.

While the particular experiment of the Federal National Council is considered to have been the only one of its type in the Arab world, the experiment of the National Consultative Council of the Emirate of Abu Dhabi shows, that its ruling family is successfully able to stay in power although having the most advanced system of governance of the United Arab Emirates. 
adoption being required. On the contrary the obiter on the legality of the Provisional Legislative Council and particularly on the limited scope of the jurisdiction of the courts in Hong Kong SAR have to be examined critically. This part of the judgement is not only doubtful under the issues of the law but also has a severe factual impact to the interpretation of the principle: "One Country Two Systems". Contrary to the position of the High Court, Art. 3 (3) of the Joint Declaration and Arts. 2, 19 and 81 of the Basic Law provide for the unlimited jurisdiction of the courts in Hong Kong SAR with respect to all decisions or resolutions concerning Hong Kong SAR. In adopting and promulgating the Basic Law as national law of the People's Republic of China and - at the same time - as the Constitution of Hong Kong SAR, the People's Republic of China agreed to observe the principles laid down in the Basic Law. This obligation to adhere to the Basic Law would be of no effect if the authorities in the People's Republic of China were to deviate from the principals of the Basic Law with no possibility of challenging such an infringement in a court in Hong Kong SAR. Moreover under this interpretation it would be unreasonable to even think of an independent judiciary within Hong Kong SAR, which would again be a violation of the explicit sections in the Joint Declaration and the Basic Law. Additionally it is doubtful, whether any act of the National People's Congress with regard to Hong Kong SAR could be challenged before a court in the People's Republic of China and if so, whether any such assessment would be that of an independent judiciary.

Hope for a reversal of this restrictive interpretation of Hong Kong SAR's autonomy under the Joint Declaration and the Basic Law by the High Court derives from the two facts that the relevant part of the judgement is obiter and not in the last instance. Hopefully the Court of Final Appeal - if conf ronted with the issues - will take a different position.

\section{Rules and Regulations of the Federal National Council of the United Arab Emirates and the National Consultative Council of the Emirate of Abu Dhabi and their Functions within the Country's Socio-political Sphere}

\section{By Monika Fatima Mühlböck}

On 2 December 1971 six of the seven Trucial states, Abu Dhabi, Dubai, Sharjah, Ajman, Umm al-Qaiwain, and Fujairah formed the United Arab Emirates. The seventh state, Ras alKhaimah, joined the federation on 10 February 1972.

The rulers of the sheikhdoms decided it was necessary to create modern forms of administration including direct democracy, in the form of the Federal National Council and the National Consultative Council, while at the same time preserving traditional institutions like the madjlis, with the vitality and legitimacy they draw from history. The Federal National Council, which deals on a country-wide level, was formally established on 13 
February 1973, whereas the National Consultative Council, which fulfills its duties within the region of the Emirate of Abu Dhabi, had already been formed on 8 July 1971.

This article focuses on the laws concerning these two bodies and gives detailed information about their development. A closer look at the traditional and federal government as well as the relationship of both permits a deeper understanding of this subject.

While the experiment of the Federal National Council is considered to have been the only one of its type in the Arab world, the venture with the National Consultative Council of the Emirate of Abu Dhabi proves, that its ruling family is successfully able to stay in power despite having the most advanced system of governance of the United Arab Emirates. 